University of Nebraska - Lincoln

DigitalCommons@University of Nebraska - Lincoln

2018

\title{
Hybrid speciation in birds, with special reference to Darwin's finches
}

G. E. Hill

R. M. Zink

University of Nebraska - Lincoln

Follow this and additional works at: https://digitalcommons.unl.edu/natrespapers

Part of the Natural Resources and Conservation Commons, Natural Resources Management and Policy Commons, and the Other Environmental Sciences Commons

Hill, G. E. and Zink, R. M., "Hybrid speciation in birds, with special reference to Darwin's finches" (2018). Papers in Natural Resources. 1415.

https://digitalcommons.unl.edu/natrespapers/1415

This Article is brought to you for free and open access by the Natural Resources, School of at DigitalCommons@University of Nebraska - Lincoln. It has been accepted for inclusion in Papers in Natural Resources by an authorized administrator of DigitalCommons@University of Nebraska - Lincoln. 


\title{
JOURNAL OF
}

\section{AV IAN $\mathrm{BIO}$ LOGY}

\section{Point-of-View}

\section{Hybrid speciation in birds, with special reference to Darwin's finches}

\author{
Geoffrey E. Hill and Robert M. Zink
}

G. E. Hill (http://orcid.org/0000-0001-8864-6495) (ghill@auburn.edu), Dept of Biological Sciences, Auburn Univ., Auburn, AL, USA. - R. M. Zink, School of Natural Resources, School of Biological Sciences, and Nebraska State Museum, Univ. of Nebraska, Lincoln, NE, USA.

\section{Journal of Avian Biology}

2018: e01879

doi: $10.1111 /$ jav.01879

Subject Editor: Staffan Bensch Editor-in-Chief: Thomas Alerstam Accepted 6 July 2018

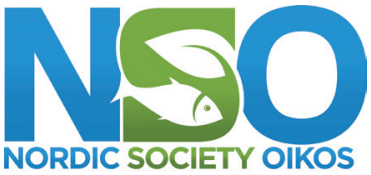

www.avianbiology.org
Keywords: species concept, gene flow, reproductive isolation

The typical model of avian speciation proposes the division of an ancestral population into two allopatric populations and subsequent evolution via natural selection, sexual selection, or genetic drift of fixed genetic differences in the daughter populations. Whether these taxa are recognized as species depends on which species concept is followed, with reproductive isolation the requirement for biological species status (Mayr 1942), diagnosability for a lineage-based concept (Cracraft 1983), and divergence of uniquely coadapted mitochondrial and nuclear genes for a mitonuclear compatibility concept (Hill 2017). Under any model of species and speciation (Wiens 2004), however, it is not a foregone conclusion that every isolated population will give rise to a new species. Mayr (1942:155) wrote 'Geographic variation is thinkable only if subspecies are incipient species. This, of course, does not mean that every subspecies will eventually develop into a good species. Far from it! All this statement implies is that every species that developed through geographic speciation had to pass through the subspecies stage.' Molecular work has confirmed Mayr's assertion.

Numerous studies have documented that hybridization between differentiated taxa can lead to breakdown of accumulated differences between diverging populations (Rhymer and Simberloff 1996, Weckstein et al. 2002, Seehausen 2006, Krosby and Rohwer 2009, Gilman and Behm 2011, Webb et al. 2011, Block et al. 2015). For example, Barrowclough et al. (1999) showed that the Canadian and U.S. populations of the barred owl Strix varia diverged when they were isolated in refugia, but that postglacial population expansion resulted in introgression over a relatively large part of the range. Kleindorfer et al. (2014) proposed that hybridization was causing the disappearance of a species of tree finch Camarhynchus in the Galapagos Islands. Webb et al. (2011) suggested that hybridization was leading to the loss of cryptic species of ravens Corvus through replacement of one divergent mitochondrial genotype with another. Thus, molecular studies have shown that differences between lineages that have not yet completed speciation as well as those that have achieved species status, can be reversed via hybridization.

Hybridization can potentially be a creative source leading to speciation. 40-70\% of all plant species are polyploids suggesting that hybridization is an important

(C) 2018 The Authors. Journal of Avian Biology (C) 2018 Nordic Society Oikos 
mechanism for plant speciation (Mallet 2007). In contrast, the percentage of hybrid species in animals is lower, and for birds in particular there are few well documented examples of hybrid speciation (Hill 2017). Only four examples of potential hybrid species have been identified in birds: Audubon's warbler Setophaga auduboni (Brelsford et al. 2011), Italian sparrow Passer italiae (Elgvin et al. 2011, Hermansen et al. 2011, Trier et al. 2014, Bailey et al. 2015), Hawaiian duck Anas wyvilliana (Lavretsky et al. 2015) and golden-crowned manakin Lepidothrix vilasboasi (Barrera-Guzmán et al. 2018). In the Audubon's Warbler, some taxonomic treatments regard it as a subspecies, although it potentially meets criteria for species under the biological, phylogenetic and mitonuclear compatibility species concepts.

It is useful to clarify criteria used to recognize hybrid species (Schumer et al. 2014). Hermansen et al. (2014) used a biological species concept when they suggested that hybrid species are 'genetically admixed taxa that are reproductively isolated from their parents'. Despite the irony that the two parental species are considered species despite their successful hybridization, this view suggests minimal criteria for hybrid species recognition. Each of the four hybrid species meet minimal criteria and have been vetted using genomics data. Lamichhaney et al. (2018) recently reported a potential fifth avian taxon that resulted from hybrid speciation. Below we comment on this report and suggest that alternative, more parsimonious interpretations exist.

Darwin's finches are among the most often-cited group of vertebrates in the speciation literature. Endemic to the Galapagos Islands, this assemblage of passerine bird species has been viewed as exemplary in revealing the process of divergence of populations in morphology and song and how such divergence gives rise to speciation (Grant 1986, Han et al. 2017). However, hybridization is common among species within the Darwin's finch genera Geospiza and Camarhynchus (Peters et al. 2017), indicating porous biological species boundaries. In fact, hybridization is credited with the erasure of several species (Grant et al. 2004, Grant and Grant 2014a, Kleindorfer et al. 2014). Given the prior importance ascribed to hybridization as a homogenizing force in the finches, we were intrigued when Lamichhaney et al. (2018) claimed that hybridization created a new species of Darwin's ground finch in three generations from a single hybridization event.

The proposal by Lamichhaney et al. (2018) of speciation in three generations stemmed from the observation of an immature male finch (number 5110) that appeared on Daphne Major in 1981 and was somewhat larger than is typical for the local Geospiza fortis population. Based on microsatellite markers, this male was first deduced to be a hybrid from a pairing of $G$. fortis $\times G$. scandens (Grant and Grant 2009), whereas Lamichhaney et al. (2018) identified it as $G$. conirostris. The fact that a single individual finch was classified as three different species by authorities on Darwin's finches speaks to the difficultly in applying current morphological species limits to Geospiza finches (McKay and Zink
2015). In fact, it took a whole genome analysis to clarify the putative phylogenetic origin of this individual.

A monumental amount of outstanding fieldwork went in to unraveling the reproductive history of male 5110 . He lived 13 years, paired with six different females and fledged at least 18 offspring, five of which became breeders (Grant and Grant 2014b). Of interest are two inbred lines, $A$ and $B$, which were sired by 5110 . The A line was featured in Grant and Grant's (2009) paper, and they noted that it was reproductively isolated from line B. However, Grant and Grant (2009:20146) noted that 'The odds would seem to be against long-term persistence of the immigrant lineage [line $\mathrm{A}$ ] as a reproductively isolated population.' In fact, line A was subsequently absorbed into G. fortis (Grant and Grant 2014b). Line B, featured in Lamichhaney et al. (2018), arose when male 5110 bred with a $G$. fortis female and produced five offspring. One of these F1 offspring mated with a $G$. fortis female, and two other F1 offspring (brother-sister) mated. A male produced from the first pairing mated with a female produced from the $\mathrm{F} 1$ brother-sister pairing and gave rise to all individuals in the 'Big Bird' lineage (e.g., line B) for the next four generations. As of 2012, there were 23 inbred individuals in this lineage (Lamichhaney et al. 2018). It is this group of 23 birds that Lamichhaney et al. (2018) consider a new species that arose via hybridization and has persisted for about the same number of generations as the potentially reproductively isolated but now extinct inbred line A. Line A was thought by Grant and Grant (2009) to be almost pure G. fortis and hence not an example of hybrid speciation, whereas line B was considered to be of hybrid origin (Lamichhaney et al. 2018).

Although Grant and Grant (2014b:260) considered the Big Bird lineage a possible example of a species 'in the making', Lamichhaney et al. (2018) reported 'The newly founded population of Darwin's finches is an incipient hybrid species, reproductively isolated and ecologically segregated from coexisting finch species.' They entitled their paper 'Rapid hybrid speciation in Darwin's finches'. We interpret these statements to indicate that the speciation process was completed and therefore a potentially new unnamed species that was the product of hybridization exists on Daphne Major. However, in their supplementary materials, Lamichhaney et al. (2018) wrote 'The newly founded population could be labeled G. conirostris, but this seems illogical since the majority component of the genomes was derived from $G$. fortis and not from $G$. conirostris. It could be labeled as a new species, for example Geospiza strenuirostris, but there has been no formal description or diagnosis, and in view of the small number of generations in which it has been reproductively isolated from G. fortis we prefer to continue referring to it as a lineage.' The lack of a designated type specimen precludes formal recognition of this name. Nonetheless, there is a stark contrast between the interpretations of Grant and Grant (2014b) and Lamichhaney et al. (2018) regarding the species status of the Big Bird lineage.

The basis for the claim of species status for the 23 finches in the Bird Bird lineage in 2012 is that they were 
reproductively isolated. The authors state, 'The new population on Daphne is reproductively isolated from one of the parent populations...'. This statement is based on the fact that for three generations close relatives in Big Bird lineage bred with each other and not with $G$. fortis finches. However, Lamichhaney et al. (2018) also stated that whether this inbred group of 23 birds (line B) '... is reproductively isolated from the other, G. conirostris on Española, is unknown because experiments have not been done there.' We consider this as weak evidence for the claim of reproductive isolation evolving in a few generations in these finches, especially given the frequency with which hybridization occurs in the finches and the fate of line A. In fact, the parent populations were not reproductively isolated: the immigrant male mated with and produced offspring with a $G$. fortis female. The next generation was not reproductively isolated from $G$. fortis because again, a $G$. fortis female paired with a hybrid. Lamichhaney et al. (2018) only noted that siblings were observed to pair with siblings across, at most, three or four generations. A few generations of inbreeding seem to us to be insufficient evidence of the evolutionary independence of a new species. A much longer time is needed to determine if the Big Bird lineage is ephemeral, as line A was. In fact, one could consider both lines A and B to be separate species, but following the sentiment of Grant and Grant (2009, 2014b), we think that three generations is too few to determine whether line B is on an irreversible evolutionary trajectory or whether it will experience the same fate as line A. Thus, the Big Bird lineage does not meet the minimum criteria used to recognize the other instances of hybrid speciation in bird species.

The morphological differences cited by Lamichhaney et al. (2018) merit attention. Other similar examples of morphological differences between Darwin's finches have not been suggested to illustrate speciation. For example, Grant and Grant (1995) reported that the large ground finch (G. magnirostris) colonized Daphne Major, that inbreeding occurred, and that the founders 'and their offspring differed significantly in bill size from immigrants that did not stay to breed'. In this instance, there was no suggestion that speciation had occurred or was occurring. A different study identified morphological differences in a population of $G$. fortis on Daphne Major (Grant and Grant 2008) as an example of natural selection in the wild, but also was not considered evidence of speciation (Grant and Grant 1995, 2002, 2014b). Grant and Grant (2002) stated that 'from 1972 to 2001, Geospiza fortis (medium ground finch) and Geospiza scandens (cactus finch) changed several times in body size and two beak traits', and that ' $[T]$ he phenotypic states of both species at the end of the 30 -year study could not have been predicted at the beginning'. Again, these ephemeral morphological changes were not considered part of a speciation process.

A finch captured on Santa Cruz Island indicates the potential plasticity of expression of bill size in Darwin's finches (Fig. 1). This bird appears to have the upper mandible of a small ground finch Geospiza fuliginosa and the lower mandible of a medium ground finch Geospiza fortis. This single

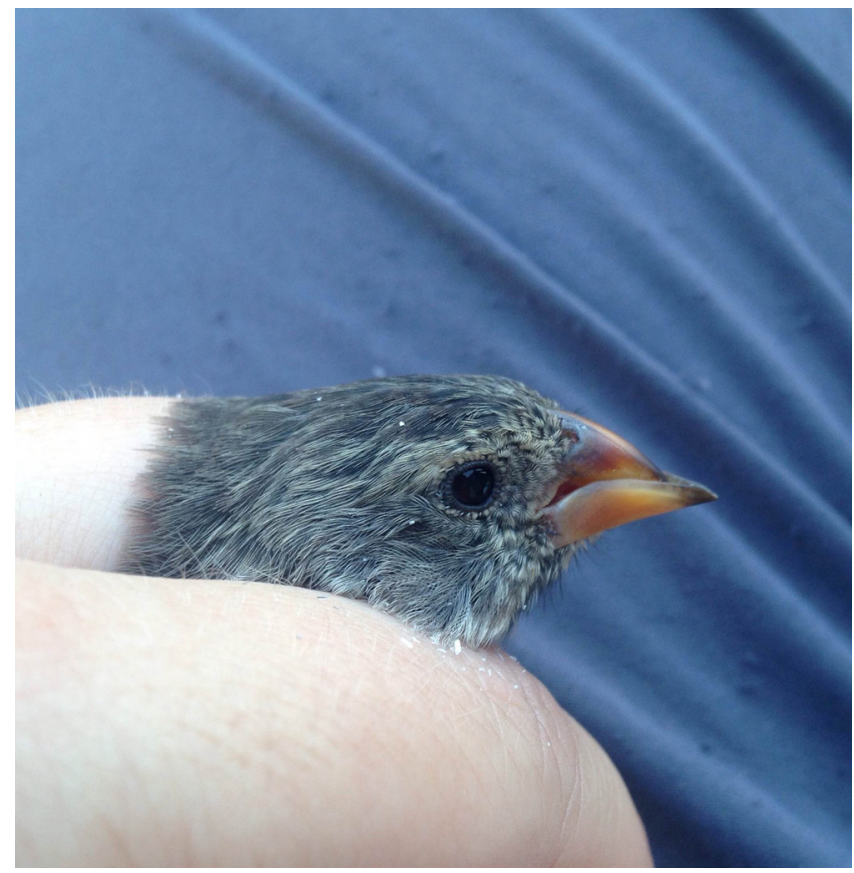

Figure 1. Finch from the Galapagos expressing a bill in which the upper mandible resembles that of a small ground finch and the lower mandible that of a medium ground finch. Photo taken at El Garrapatero on Santa Cruz Island. Photo courtesy of S. Knutie.

bill spans the range of variation shown in finch species and their putative hybrids (Grant and Grant 2009). Whether this individual represents mis-expression of two bill-size gene complexes (Abzhanov et al. 2006) or is an effect of the environment during development, it reveals the plasticity of apparent species-specific differences in beak morphology in these finches. Together, these observations complicate interpretation of the reported changes in bill size of the Big Bird population because they are also typical of ephemeral changes in finch beak morphology in populations and even a single individual, suggesting that beak morphology is an insufficient indicator of incipient speciation in this group of birds.

Based on morphological and DNA sequence data, McKay and Zink (2015) argued that Geospiza is trapped in a cycle of Sisyphean evolution, in which an 'ever-changing adaptive landscape combined with pervasive introgression among ecomorphs prevents completion of the speciation process and the maintenance of discrete, isolated gene pools or evolutionarily independent lineages.' Indeed, the observations of Grant et al. 2004 and Grant and Grant (2014b) on lines A and B are as consistent with the McKay and Zink (2015) model as they are with a hypothesis of hybrid speciation, although the genomic evidence strongly suggests that there are multiple species of Geospiza (Cadena et al. 2017, Lamichhaney et al. 2018). We suggest that the carefully documented changes in morphology and the (short-term) existence of reproductively isolated inbred lineages provide fascinating glimpses into the early stages of divergence of new lineages. Undoubtedly, such events occur in small continental populations, but they are 
far easier to observe in island settings. The long-term evolutionary consequences of these changes, however, are difficult to judge after only a few generations (Mayr 1942).

\section{Conclusions}

There are approximately 10000 biological species of birds recognized by most taxonomic authorities (Barrowclough et al. 2016). At present, only four bird species, about $0.05 \%$ of the world's biological species of birds, have been convincingly described as resulting from hybrid speciation. Although hybridization might involve cryptic lineages that are at present unrecognized (Ottenburghs et al. 2015), it is our opinion that speciation resulting from hybridization of distinct species is not an frequent mechanism of speciation in birds (Price 2008). Given the paucity of documented cases of hybrid speciation in birds and conventional theory that invokes tens of thousands of years or more for species to give rise to daughter species, the claim of speciation in a lineage of birds in only three generations (Lamichhaney et al. 2018) is extraordinary. Moreover, the claim of hybrid speciation in three generations is made in the avian group that is already a textbook example for the significance of gene flow and introgression in eroding species boundaries. The acknowledged fate of line A is a clear-cut example. We view the hybridization event reported in Lamichhaney et al. (2018) to be an instance of local assortative mating and commonly observed morphological changes brought about by natural selection that are unlikely to have a long-term evolutionary consequence (speciation).

Acknowledgements - We thank R. Holzenthal and B. Ratcliffe for discussion of taxonomy. Two anonymous reviewers provided helpful comments.

Author contributions - Both authors contributed equally to this paper.

\section{References}

Abzhanov, A., Kuo, W. P., Hartmann, C., Grant, B. R., Grant, P. R. and Tabin, C. J. 2006. The calmodulin pathway and evolution of elongated beak morphology in Darwin's finches. - Nature 442: 563-567.

Bailey, R. I., Tesaker, M. R., Trier, C. N. and Saetre, G. P. 2015. Strong selection on male plumage in a hybrid zone between a hybrid bird species and one of its parents. - J. Evol. Biol. 28: 1257-1269.

Barrera-Guzmán, A. O., Aleixo, A., Shawkey, M. D. and Weir, J. T. 2018. Hybrid speciation leads to novel male secondary sexual ornamentation of an Amazonian bird. - Proc. Natl Acad. Sci. USA 115: E218-E225.

Barrowclough, G. F., Gutierrez, R. J. and Groth, J. G. 1999. Phylogeography of spotted owl (Strix occidentalis) populations based on mitochondrial DNA sequences: gene flow, genetic structure, and a novel biogeographic pattern. - Evolution 53: 919-931.
Barrowclough, G. F., Cracraft, J., Klicka, J. and Zink, R. M. 2016. How many kinds of birds are there and why does it matter? - PloS One 11: e0166307.

Block, N. L., Goodman, S. M., Hackett, S. J., Bates, J. M. and Raherilalao, M. J. 2015. Potential merger of ancient lineages in a passerine bird discovered based on evidence from host-specific ectoparasites. - Ecol. Evol. 5: 3743-3755.

Brelsford, A., Mila, B. and Irwin, D. E. 2011. Hybrid origin of Audubon's warbler. - Mol. Ecol. 20: 2380-2389.

Cadena, C. D., Zapata, F. and Jiménez, I. 2017. Issues and perspectives in species delimitation using phenotypic data: Atlantean evolution in Darwin's finches. - Syst. Biol. 67: 181-194.

Cracraft, J. 1983. Species concepts and speciation analysis. - Curr. Ornithol. 1: 159-187.

Elgvin, T. O., Hermansen, J. S., Fijarczyk, A., Bonnet, T., Borge, T., Saether, S. A., Voje, K. L. and Sætre, G. 2011. Hybrid speciation in sparrows II: a role for sex chromosomes? - Mol. Ecol. 20: 3823-3837.

Gilman, R. T. and Behm, J. E. 2011. Hybridization, species collapse, and species reemergence after disturbance to premating mechanisms of reproductive isolation. - Evolution 65: 2592-2605.

Grant, P. R. 1986. Ecology and evolution of Darwin's finches. - Princeton Univ. Press.

Grant, P. R. and Grant, B. R. 1995. The founding of a new population of Darwin's finches. - Evolution 49: 229-240.

Grant, P. R. and Grant, B. R. 2002. Unpredictable evolution in a 30-year study of Darwin's finches. - Science 296: 707-711.

Grant, P. R. and Grant, R. B. 2008. How and why species multiply: the radiation of Darwin's finches. - Princeton Univ. Press.

Grant, P. R. and Grant, B. R. 2009. The secondary contact phase of allopatric speciation in Darwin's finches. - Proc. Natl Acad. Sci. USA 106: 20141-20148.

Grant, P. R. and Grant, B. R. 2014a. Evolutionary biology: speciation undone. - Nature 507: 178-179.

Grant, P. R., and Grant, B. R. 2014b. 40 years of evolution: Darwin's finches on Daphne Major Island. - Princeton Univ. Press.

Grant, P. R., Grant, B. R., Markert, J. A., Keller, L. F. and Petren, K. 2004. Convergent evolution of Darwin's finches caused by introgressive hybrizarion and selection. - Evolution 58: 1588-1599.

Han, F., Lamichhaney, S., Grant, B. R., Grant, P. R., Andersson, L. and Webster, M. T. 2017. Gene flow, ancient polymorphism, and ecological adaptation shape the genomic landscape of divergence among Darwin's finches. - Genome Res. 27: 1004-1015.

Hermansen, J. S., Saether, S. A., Elgvin, T. O., Borge, T., Hjelle, E. and Sætre, G. 2011. Hybrid speciation in sparrows I: phenotypic intermediacy, genetic admixture and barriers to gene flow. - Mol. Ecol. 20: 3812-3822.

Hermansen, J. S., Haas, F., Trier, C. N., Bailey, R. I., Nederbragt, A. J., Marzal, A. and Sætre, G. 2014. Hybrid speciation through sorting of parental incompatibilities in Italian sparrows. - Mol. Ecol. 23: 5831-5842.

Hill, G. E. 2017. The mitonuclear compatibility species concept. - Auk 134: 393-409.

Kleindorfer, S., O’Connor, J. A., Dudaniec, R. Y., Myers, S. A., Robertson, J. and Sulloway, F. J. 2014. Species collapse via hybridization in Darwin's tree finches. - Am. Nat. 183: 325-341. 
Krosby, M. and Rohwer, S. 2009. A $2000 \mathrm{~km}$ genetic wake yields evidence for northern glacial refugia and hybrid zone movement in a pair of songbirds. - Proc. R. Soc. B 276: 615-621.

Lamichhaney, S., Han, F., Webster, M. T., Andersson, L., Grant, B. R. and Grant, P. R. 2018. Rapid hybrid speciation in Darwin's finches. - Science 359: 224-228.

Lavretsky, P., Dacosta, J. M., Hernández-Baños, B. E., Engilis, A., Sorenson, M. D. and Peters, J. L. 2015. Speciation genomics and a role for the $\mathrm{Z}$ chromosome in the early stages of divergence between Mexican ducks and mallards. - Mol. Ecol. 24: 5364-5378.

Mallet, J. 2007. Hybrid speciation. - Nature 446: 279-283.

Mayr, E. 1942. Systematics and the origin of species. - Columbia Univ. Press.

McKay, B. D. and Zink, R. M. 2015. Sisyphean evolution in Darwin's finches. - Biol. Rev. 90: 689-698.

Ottenburghs, J., Ydenberg, R. C., Van Hooft, P., Van Wieren, S. E. and Prins, H. H. T. 2015. The avian hybrids project: gathering the scientific literature on avian hybridization. - Ibis 157: 892-894.

Peters, K. J., Myers, S. A., Dudaniec, R. Y., O’Connor, J. A. and Kleindorfer, S. 2017. Females drive asymmetrical introgression from rare to common species in Darwin's tree finches. - J. Evol. Biol. 30: 1940-1952.

Price, T. 2008. Speciation in birds. - Roberts and Company.

Rhymer, J. M. and Simberloff, D. 1996. Extinction by hybridization and introgression. - Annu. Rev. Ecol. Syst. 27: 83-109.

Schumer, M, Rosenthal, G.G. and Andolfatto, P. 2014. How common is homoploid hybrid speciation? - Evolution 68: $1553-1560$.

Seehausen, O. 2006. Conservation: losing biodiversity by reverse speciation. - Curr. Biol. 16: R334-R337.

Trier, C. N., Hermansen, J. S., Sætre, G.-P. and Bailey, R. I. 2014. Evidence for mito-nuclear and sex-linked reproductive barriers between the hybrid 'Italian' sparrow and its parent species. - PLoS Genet. 10: e1004075.

Webb, W. C., Marzluff, J. M. and Omland, K. E. 2011. Random interbreeding between cryptic lineages of the common raven: Evidence for speciation in reverse. - Mol. Ecol. 20: 2390-2402.

Weckstein, J., Afton, A., Zink, R. and Alisauskas, R. 2002. Hybridization and population subdivision within and between Ross's geese and lesser snow geese: a molecular perspective. - Condor 104: 432-436.

Wiens, J. J. 2004. What is speciation and how should we study it? - Am. Nat. 163: 914-923. 